Tatiana KRYNICKA*

\title{
„DESINE GENTILIBUS IAM INSERVIRE POETIS...” (VERSUS XI 9). CHRZEŚCIJAŃSCY EPICY W BIBLIOTECE IZYDORA Z SEWILLI
}

„Niewiedza jest matką wszystkich błędów” - orzekli w 633 r. ojcowie IV synodu toledańskiego, którego obradom przewodniczył i wywarł znaczący wpływ na redakcję jego kanonów ${ }^{2}$ uczony biskup Sewilli Izydor (560-636) potomek wspaniałego hiszpano-rzymskiego rodu, doradca wizygockich królów, żarliwy wyznawca Chrystusa, błyskotliwy erudyta, postrzegający krzewienie wiedzy - o Stwórcy, lecz również o stworzonym przez niego świecie - jako jeden z najważniejszych duszpasterskich obowiązków. Właśnie dlatego skomponował liczne pisma o charakterze doktrynalnym, egzegetycznym, historycznym, gramatycznym i dydaktycznym. Każde spośród nich było odpowiedzią na potrzeby i wymogi jego współczesnych ${ }^{3}$; wszystkie zaś przetrwały czasy swego autora i posłużyły jako źródło wiedzy dla wielu pokoleń Europejczyków ${ }^{4}$.

Izydor nie był oryginalnym myślicielem, nie stworzył też nowych systemów filozoficznych, nie wytyczył nowych kierunków teologicznych rozważań, ani nie prowadził własnych badań przyrodniczych. Był natomiast wielkim kompilatorem, który potrafił w sposób zwięzły, przejrzysty, uporządkowany, i dzięki temu przystępny, przekazać czytelnikowi wiadomości znajdujące się w wielu obszernych, trudnych i coraz bardziej niedostępnych ogółowi pismach $^{5}$. Słynna biblioteka sewilskich biskupów, w której encyklopedysta

* Dr Tatiana Krynicka - adiunkt w Katedrze Filologii Klasycznej na Wydziale Filologicznym Uniwersytetu Gdańskiego; e-mail: tatianatko@yahoo.es.

${ }^{1}$ Concilium Toletanum IV (a. 633) can. 25, ed. J. Vives: Concilios visigóticos y espano-romanos, Barcelona - Madrid 1963, 202 lub PL 130, 471D-472A: „Ignorantia mater cunctorum errorum maxime in sacerdotibus vitanda est"; por. też M. Starowieyski, Przygotowanie do kapłaństwa w Hiszpanii Wizygockiej, VoxP 13-15 (1993-1995) t. 24-29, 279, nota 21.

${ }^{2}$ Por. J. Madóz, San Isidoro de Sevilla. Semblanza de su personalidad litararia, León 1960, 12-14; J. Fontaine, Le monde latin et la Bible, Paris 1985, 298-301; Starowieyski, Przygotowanie, s. $279-280$.

${ }^{3}$ Por. M.C. Díaz y Díaz, Introducción general a San Isidoro de Sevilla, w: San Isidoro de Sevilla, Etimologías, Edición bilingüe, texto latino, versión española y notas por J. Oroz Reta - M.-A. Marcos Casquero, t. 1, Biblioteca de Autores Cristianos 433, Madrid 1982, 7.

${ }^{4}$ Por. T. Krynicka, Izydor z Sewilli, Kraków 2007, $17-76$.

${ }^{5}$ Por. M. Menéndez y Pelayo, Escritos de crítica literaria, Madrid 1884, 137-138, cyt. za 
spędził swą młodość, czytając i sporządzając notatki z tego, co przeczytał, zaginęła. Możemy jednak próbować odtworzyć jej katalog w oparciu o lekturę jego utworów.

\section{STOSUNEK IZYDORA DO POEZJI}

Izydor traktuje pisma źródłowe ze swobodą cechującą mistrza. Snując własną opowieść o świecie, łączy w jedną kunsztowną mozaikę wiadomości pochodzące z pism klasycznych i chrześcijańskich, z dzieł komentowanych oraz komentarzy, z kompletnych oryginałów jak również ze sporządzonych na ich podstawie ekscerptów, streszczeń i przeróbek. Zgodnie z przyjętym w starożytności zwyczajem wyjątkowo rzadko podaje imiona autorów swoich źródeł. Najczęściej cytuje imiennie poetów, także epików. Odbiorca słynnych Etymologii, nieświadomy tego, iż ma do czynienia z dziełem kompilatora, gotów byłby pomyśleć, że czyta utwór prozaika ozdobiony przez autora cytatami z poematów Enniusza, Wergiliusza, Owidiusza, czy Lukana. Poeci nie dostarczają mu z reguły wiadomości o świecie. Niekiedy potwierdzają niejako słuszność jego wywodów; pomagają mu w wyjaśnieniu źródłosłowów łacińskich wyrazów. Jak się wydaje, Izydor wprowadza do swej encyklopedii fragmenty utworów poetyckich przede wszystkim dlatego, że chce upiększyć własne dzieło, a także, by popisać się swą znajomością łacińskiej poezji. Wyprowadzając nazwę używanych do barwienia tkanin grzybów lechenizowanych fucus od innego znaczenia słowa fucus - obłuda, pozór - odwołuje się do znanego wersu IV Bukoliki, w którym wełna uczy się udawania kolorów6 Ponadto wie o tym, że wyraz fucus określa także trutnia. Prezentując czytelnikowi tego większego od pszczół, a mniejszego od szerszenia owada, który w swej gnuśności żywi się owocami czyjejś pracy (quasi fagus), Izydor cytuje fragment Georgik Wergliusza; czyni to, zauważmy, niedokładnie i całkowicie zmieniając sens jego wypowiedzi ${ }^{7}$.

C. López Bravo, El legado iusfilósofico [sic!] de San Isidoro de Sevilla. Ley y derecho en el libro $V$ de las „Etimologías”, „Isidorianum” 23 (2003) 12-13, thum. własne: „Izydor przynależał do dwu społeczności, z których jedna już dogorywała i umierała, druga wciąż jeszcze była w powijakach, półdzika, nie posiadająca umiejętności, nie znająca nauki. [...] Jego wielkie przedsięwzięcie polegało na przekazaniu tej drugiej dorobku tej pierwszej [...] uczynił to, i dlatego wszystkie możliwe pochwały, które zdolny jest wyrazić ludzki język, należą mu się bardziej, niż gdyby stworzył nowe systemy filozoficzne" - ta wypowiedź o Izydorze jest, być może, nieco patetyczna, ale poprzez to nie przestaje być sprawiedliwa; zob. też V. Ukolova, The Last of the Romans and European Culture, Moscow 1989, 304-305.

${ }^{6}$ Por. Isidorus, Etymologiae XVII 9, 98, ed. J. André: Isidore de Séville, Étymologies. Livre XVII: De l'agriculture, Paris 1981, 221: „Fucus genus herbae est de qua tinguitur vestis, dicta quia mentitur alienum colorem. Unde et Vergilius: discet mentiri lana colores"; zob. Vergilius, Ecloga IV 42: „,nec varios discet mentiri lana colores”.

${ }^{7}$ Por. Isidorus, Etymologiae XII 8, 3, ed. J. André: Isidore de Séville, Étymologies. Livre XII: Des animaux, Paris 1986, 289: „Fucus est maior ape, scabrone minor. Dictus autem fucus quod 
Mimo że autor Etymologii był jednym z najbardziej wykształconych ludzi swoich czasów, jego znajomość klasycznej literatury pozostawia sporo do życzenia. Wygląda na to, że utożsamiał Marka Terencjusza Warrona z Warronem Atacyńskim, gdyż cytuje obu jako „Varro”. . Nie jesteśmy pewni, czy znał klasycznych epików bezpośrednio, czy też - co jest bardziej prawdopodobne - pośrednio, głównie dzięki cytującym ich gramatykom. Powodem, dla którego biskup Sewilli nie sięgał do oryginałów, było - jak się wydaje - jedynie ubóstwo dostępnych mu księgozbiorów. Albowiem nie ulega wątpliwości, że ten wrażliwy na słowo erudyta doceniał piękno poezji i chętnie sięgał do utworów wielkich poetów, nawet jeśli miał dostęp jedynie do ich fragmentów zamieszczonych w wyciągach, antologiach i komentarzach ${ }^{9}$. Wyrazy, dla których przytacza cytowane wiersze w Etymologiach, znajdują się najczęściej na początku bądź na końcu wersu, a nawet zawierają drugą czy trzecią od końca wersu sylabę, czyli występują w pozycjach najbardziej dogodnych do zapamiętania tekstu napisanego $\mathrm{w}$ heksametrze ${ }^{10}$. W związku $\mathrm{z}$ tym możemy zaryzykować stwierdzenie, iż Izydor cytuje poetów bez sięgania do notatek i fiszek, z pamięci, co zapewne dowodzi jego miłości do poezji. Wprawdzie w Sentencjach - bardzo ważnym, najpóźniejszym dziele Sewilczyka, będącym swego rodzaju summą teologiczną i wademekum doskonałego chrześcijańskiego życia ${ }^{11}$ - wyraża on podzielane przez wielu chrześcijan przekonanie, iż snując czcze opowieści pogańscy poeci dostarczają ludzkiemu umysłowi zgubnej przyjemności, za pomocą której pobudzają go do uległości wobec bodźców żądz. W związku z tym stwierdza kategorycznie, iż wyznawcom Chrystusa nie wolno czytać kłamstw poetów (figmenta poetarum) ${ }^{12}$. Jak to się ma do jego własnej postawy wobec klasycznej poezji? Zmienił zdanie? Był hipokrytą ${ }^{13}$ ? Narzucał innym wymogi, których nie spełniał sam? Do znalezienia właściwej odpowiedzi na te pytania prowadzą nas kolejne pisma Izydora.

alienos labores edat, quasi fagus [...]. Ignavum fucus pecus a praesepibus arcet”; zob. Vergilius,. Georgica IV 168: „Ignavum fucos pecus a praesepibus arcent [scil. apes]”.

${ }^{8}$ Por. Isidorus, Etymologiae XVII 7, 57-58; 9, 95, ed. André, s. 127-129 i 219. Pisze o tym M. Starowieyski, Obraz literatury klasycznej pogańskiej w dziełach Izydora z Sewilli. Literatura rzymska, „Meander” 30 (1975) 27.

${ }^{9}$ Tak twierdzi, czyniąc wyjątek jedynie dla Wergiliusza, wybitny izydorianista J. Fontaine (Isidore de Séville et la culture classique dans l'Espagne wisigothique, t. 3, Paris 1983, 742-744).

${ }^{10}$ Zwraca na to uwagę V.J. Herrero Llorente (Lucano en la literatura hispanolatina, „Emerita” 27 (1959) 45-52).

${ }^{11}$ Por. T. Krynicka, Wprowadzenie, w: Izydor z Sewilli, Sentencje, tłum. i oprac. T. Krynicka, ŹMT 66, Kraków 2012, 5-28.

${ }^{12}$ Por. Isidorus, Sententiae III 13, 1, ed. P. Cazier, CCL 111, Turnhout 1998, 236: „Ideo prohibetur christianus figmenta legere poetarum quia per oblectamenta inanium fabularum mentem excitant ad incentiva libidinum".

${ }^{13}$ Trudno zrozumieć powody, dla których E.R. Curtius (Literatura europejska i łacińskie średniowiecze, tłum. A. Borowski, Kraków 1997, 473-474) uważa, iż wypowiadając się w ten sposób autor Sentencji nie wyraża swej osobistej opinii, a jedynie dostosowuje się do postanowień IV synodu w Kartaginie (398). 
Przyglądając się radom, które uczony biskup kieruje do mnichów znajdującej się niedaleko Sewilli honoriańskiej wspólnoty, zauważamy, iż w odróżnieniu od autorów innych, wcześniejszych oraz współczesnych mu reguł, nie odmawia pogańskim poetom prawa wstępu do klasztornych bibliotek. Przestrzega jedynie przed niebezpieczeństwami, które czyhają w zwojach pogańskich ksiąg na mnichów, którzy nie są do ich lektury wystarczająco przygotowa$\mathrm{ni}^{14}$. A zatem swoją znajomość utworów antycznych poetów Sewilczyk mógł usprawiedliwiać tym, że w pierwszej kolejności zgłębiał naukę biblijną oraz pisma autorów chrześcijańskich, które zawierają prawdę objawioną, wyrażoną językiem niewykwintnym, lecz pełnym mocy i mądrości ${ }^{15}$. Powyższy zakaz stanowi zatem dowód zarówno jego roztropności i odpowiedzialności za dusze powierzonych mu mnichów, jak też - z drugiej strony - wyjątkowej życzliwości uczonego biskupa wobec klasycznej literatury.

\section{POECI W WIERSZACH SEWILCZYKA}

O miłości Izydora do klasycznej poezji świadczą ponadto liczne reminiscencje z poetów, również pogan (Marcjalisa, Wergiliusza, Klaudiana) w epigramatach samego Sewilczyka. Uczony biskup, podobnie jak wielu innych przedstawicieli współczesnych mu wizygockich elit, uległ bowiem modzie pisania wierszy i pozostawił szereg drobnych, acz zasługujących na uwage utworów poetyckich, nacechowanych wysoką koncentracją środków artystycznych i zdradzających znajomość klasycznych wzorców. Większość z nich tworzy zbiór, który w najstarszych rękopisach występuje pod tytułem Wiersze (Versus $)^{16}$. Składa się on z 27 skomponowanych w dystychu elegijnym epigramatów różnej (od 2 do 10 wersów) długości. Izydor oprowadza w nich czytelnika po swojej bibliotece (ep. 1-15) oraz sąsiadujących z nią pomieszczeniach: aptece (ep. 16-24) i skryptorium (ep. 25-27). W epigramatach poświęconych księgozbiorowi, które - zgodnie ze starożytnym zwyczajem - mogły zdobić mury słynnej biblioteki sewilskich biskupów, prezentuje autorów, których dzieła w niej się znajdowały oraz wyraża swoją opinię o ich twórczości ${ }^{17}$. $\mathrm{Na}$

${ }^{14}$ Por. Isidorus, Regula monachorum 8, 3, PL 83, 877-878: „Gentilium libros vel haereticorum volumina monachus legere caveat; melius est enim eorum perniciosa dogmata ignorare, quam per experientiam in aliquem laqueum erroris incurrere". Podobnie interpretuje wypowiedź Izydora P. Riché, Edukacja i kultura w Europie Zachodniej (VI-VIII wiek), tłum. M. Radożycka-Paoletti, Warszawa 1995, 305-307.

${ }^{15}$ Por. Isidorus, Sententiae III 13, 2-7, CCL 111, 236-237.

${ }^{16}$ Por. tenże, Versus, ed. J.M. Sánchez Martín, CCL 113A, Turnhout 2000, 207-250 (cum commentario et translatione), lub PL 83, 1107-1111. W Antyfonarzu z León znajdujemy ponadto Laus Cerei (ed. L. Brou: Problèmes liturgiques chez Saint Isidore, w: Isidoriana, ed. M.C. Díaz y Díaz, León 1961, 195-197) - skomponowany przez Izydora hymn na Wielką Sobotę, do którego biskup Sewilli ułożył prawdopodobnie także melodię.

${ }^{17}$ Por. T. Krynicka, Wstęp, w: Św. Izydor z Sewilli, Wiersze (Versus, CPL 1212), VoxP 27 (2007) t. 50-51, 566-568. 
pierwszym miejscu wymienia księgę ksiąg, czyli Biblię; w kolejnych utworach przedstawia zaś chrześcijańskich teologów i historyków, a także prawników oraz poetów. „Sunt hic plura sacra, sunt mundialia plura” - obwieszcza Izydor. Zakładając, iż jego gość jest wykształconym, a więc należycie przygotowanym do lektury czytelnikiem, zachęca, aby czytał to, na co ma ochotę, nawet gdyby były to utwory poetów: „Ex his si qua placent carmina tolle, lege" ${ }^{18}$. Następnie uspokaja odbiorcę, którego odraża (horret) i napawa wstrętem (tedet) lektura poetów klasycznych - Wergiliusza, Horacego, Owidiusza, Persjusza, Lukana i Stacjusza - zachęcając go, aby sięgnął po poematy napisane przez chrześcijan. Proponuje uwadze czytelnika czterech autorów, spośród których jeden - Juwenkus - skomponował jedynie poemat epicki, trzej pozostali zaś - Prudencjusz, Awit z Bragi, Seduliusz - zasłynęli również jako epicy. Zauważmy, iż użycie przez pogodnego biskupa tak mocnych wyrazów jak horret i tedet, jego znajomość klasycznych poetów, jak również specyficzne poczucie humoru, które w Sentencjach kazało mu stwierdzić, iż gramatycy są ostatecznie lepsi od heretyków ${ }^{19}$, pozwala nam przypuścić, iż obecny w Wierszach odgłos toczonej w czasach Izydora poważnej debaty co do wyższości poetów chrześcijańskich nad poganami ma wydźwięk żartobli$\mathrm{wy}^{20}$. W Wierszach Biskup Sewilli puszcza do czytelnika oko, a nie przemawia jak rygorystyczny autor indeksu książek zakazanych czy też, jak chce Ernst Robert Curtius, jak człowiek, którego cechuje „bezosobista tolerancja”21.

1. Prudencjusz. Przyjęta przez Izydora kolejność wyliczania chrześcijańskich poetów jest trudna do wyjaśnienia. Nie kieruje się on względami chronologicznymi ani miejscem pochodzenia poetów. Nie posługuje się też gradacją, gdyż na pierwszym miejscu wymienia autora, którego, jak się wydaje, ocenia najwyżej. Jest to Prudencjusz (Aurelius Prudentius Clemens), któremu poświęca aż dwa wersy (dla porównania Awitowi z Vienne - 1, Juwenkusowi i Seduliuszowi wspólnie - 3). Sewilczyk wyraża się nader pochlebnie o spuściźnie wszystkich autorów prezentowanych w zbiorze, jednak jego opinia o twórczości Prudencjusza nawet na tle innych pochwalnych epigramatów ma wymowę wręcz przesadną. Izydor nazywa go poetą wybornym i pełnym słodyczy, chciałoby się powiedzieć, miodopłynnym: „eximio dulcis Prudentius ore". Następnie, niejako rozładowując podniosły ton tej pochwały, stwierdza żartobliwie, iż dzięki swoim różnorodnym utworom poetyckim (variis carminibus) Prudencjusz jest wystarczająco znakomity (nobilis ... satis), zapewne

${ }^{18}$ Isidorus, Versus II 1-2, CCL 113A, 213.

${ }^{19}$ Por. Isidorus, Sententiae III 13, 11, CCL 111, 238: „Meliores esse grammaticos quam hereticos; heretici enim haustum letiferi sucus hominibus persuadendo propinant; grammaticorum autem doctrina potest etiam proficere ad vitam, dum fuerit in meliores usus adsumpta".

${ }^{20}$ Por. J. Fontaine, Isidore de Séville. Genèse et originalité de la culture hispanique au temps de Wisigoths, Turnhout 2001, 350.

${ }^{21}$ Curtius, Literatura, s. 473. 
nawet dla tak wymagającego czytelnika jak ten, który właśnie poszukuje w biskupiej bibliotece godnej siebie lektury ${ }^{22}$. Zaznaczmy, iż również spoglądający na spuściznę Prudencjusza z perspektywy wieków nowożytni uczeni dochodzą do wniosku o epokowym znaczeniu tego poety, który ,,jako pierwszy wyniósł poezję chrześcijańską do wysokości poezji klasycznej"23. Biorąc to pod uwagę, powinniśmy stwierdzić, iż dając tak pochlebną opinię o twórczości „chrześcijańskiego Horacego"24 Izydor jawi się nam jako znawca literatury, zdolny do wydania trafnego sądu o wartości dzieła literackiego i znaczeniu jego twórcy.

Izydor mówi o różnorodnych utworach Prudencjusza ${ }^{25}$, lecz nie podaje, niestety, tytułów tych spośród nich, które miały się znajdować w jego księgozbiorze. Możemy jednak przypuścić, iż nie zabrakło tam żadnego poematu owego popularnego w wizygockiej Hiszpanii - również ze względu na swe pochodzenie z Półwyspu Iberyjskiego - twórcy ${ }^{26}$. Żyjący na przełomie IV i V w. Prudencjusz był poetą nie tylko utalentowanym, lecz również bardzo płodnym $^{27}$. Znamy 10890 skomponowanych przez niego wersów, co stanowi tylko niewiele mniej niż dorobek Wergiliusza (12908 ww.), lecz zdecydowanie więcej niż spuścizna Horacego $(6527 \text { ww. })^{28}$. Pozostawił po sobie hymny, zbiór epigramatów, utwory liryczne, a także cztery poematy dydaktyczne skomponowane w heksametrze ukazujące walkę wyznawcy Chrystusa o prawdę, cnotę i wiarę ${ }^{29}$. Są to: nawiązujący do sporów wokół usunięcia ołtarza Wiktorii z Senatu poemat Contra Symmachum; poświęcona problematyce grzechu pierworodnego Hamartigenia; wymierzona w heretyków teologiczno-polemiczna Apotheosis oraz Psychomachia - pierwszy w literaturze europejskiej poemat alegoryczno-moralny, jeden z najbardziej poczytnych dzieł Pruden-

${ }^{22}$ Por. Isidorus, Versus XI 3-4, CCL 113A, 223: „Pareat eximio dulcis Prudentius ore / carminibus variis nobilis ille satis".

${ }^{23}$ J.M. Szymusiak - M. Starowieyski, Prudencjusz, SWP 337; por. J. Fontaine, Chrześcijańska literatura łacińska. Rys historyczny, thum. J. Słomka, Tarnów 1997, 145-149; M. Cytowska H. Szelest, Literatura rzymska. Okres cesarstwa. Autorzy chrześcijańscy, Warszawa 1994, 225-226.

${ }^{24}$ Według określenia B. Gładysza (Święto Trzech Króli a „,chrześcijański Horacy”, „,Kurjer Poznański" 1928, nr 8, 8).

${ }^{25}$ Zauważmy, iż varius to również różnokolorowy, mieniący się różnymi barwami, a w odniesieniu do osoby - wszechstronny, por. Plezia V 535, sv. varius.

${ }^{26}$ O znajomości Prudencjusza w wizygockiej Hiszpanii por. M.C. Díaz y Díaz, Prudencio en la España visigótica: unas breves notas, w: Corona gratiarum. Miscellanea patristica, historica et liturgica E. Deccers, t. 2, Brugge 1975, 61-70. O jego recepcji w średniowiecznej Galii, Italii, Irlandii, Anglii oraz w epokach późniejszych por. M. Starowieyski, Wstęp, w: Aureliusz Prudencjusz Klemens, Wieńce męczeńskie (Peristephanon), tłum. M. Brożek, ŹMT 40, Kraków 2006, 92-97; H. Waddell, Średniowiecze wagantów, tłum. Z. Wrzeszcz, Warszawa 1960, 60-67.

${ }^{27}$ Omówienie życia i twórczości Prudencjusza por. Cytowska - Szelest, Literatura rzymska, s. $195-226$.

${ }^{28}$ Powyższe obliczenia podaję za M. Starowieyskim (Wstęp, ŹMT 40, 47).

${ }^{29}$ Por. tamże, s. 52. 
cjusza obok jego Księgi hymnów codziennych (Kathemerinon) ${ }^{30}$. Treść Walki duszy stanowią opisane w sposób plastyczny i realistyczny, wręcz makabryczno-realistyczny, staczane $\mathrm{w}$ duszy ludzkiej pojedynki upersonifikowanych Cnót z upersonifikowanymi Wadami. Poemat odpowiada gustom rzymskiego czytelnika, który chętnie uosabiał abstrakcyjne pojęcia ${ }^{31}$. Jest napisany piękną łaciną, zdradzającą wpływ lektury epików klasycznych, przede wszystkim zaś Wergiliusza. Jest to zarazem utwór głęboko chrześcijański. Autor cały czas nawiązuje do Biblii, którą interpretuje stosując metodę alegoryczną ad figuram. Operuje teologicznymi pojęciami nawrócenia i łaski; w centrum jego uwagi znajduje się Chrystus, który utwierdza chrześcijanina w walce ze złem. Słusznie zatem ks. Marek Starowieyski zwraca uwagę na praktyczny, katechetyczno-ascetyczny wymiar utworu ${ }^{32}$.

Tworząc zbiory hymnów dla czytania i medytacji Prudencjusz podążał w kierunku wyznaczonym przez „pionierów hymnografii chrześcijańskiej” - Hilarego z Poitiers oraz Mariusza Wiktoryna ${ }^{33}$, a przede wszystkim zaś Ambrożego z Mediolanu ${ }^{34}$ - twórcę hymnografii chrześcijańskiej, autora wytwornych, głębokich teologicznie, a zarazem prostych i łatwych w wykonaniu dzięki zastosowaniu dymetru jambicznego, hymnów liturgicznych. Hymny Ambrożego naśladowali liczni anonimowi poeci, entuzjastycznie śpiewali wierni $^{35}$, znajdywał $\mathrm{w}$ nich też pocieszenie pełen bólu po śmierci matki Augustyn $^{36}$. Nie zabrakło ich również w bibliotece Izydora. Jednak wyczuwając, iż biskup Mediolanu stał się poetą - według określenia jednego z badaczy - „niejako przypadkowo, pod presją okoliczności duszpasterskich" ${ }^{\text {37 }}$, Izydor wspomina o jego hymnach mimochodem i nie omawia Ambrożego obok innych poetów ${ }^{38}$.

2. Awit $\mathbf{z}$ Vienne. Na drugim miejscu w sporządzonym przez Izydora wykazie chrześcijańskich poetów znajduje się Awit z Vienne (Alcimius Ecdicius Avitus). Awitus żył na przełomie V i VI w. Wywodził się ze znakomitej rodziny senatorskiej, był krewnym cesarza Eparchiusza Awitusa (455-456),

\footnotetext{
${ }^{30}$ Por. tamże, s. 93 i 98-99.

${ }^{31}$ Wcześniejsze, pogańskie i chrześcijańskie personifikacje Fides pobieżnie omawia S. Stabryła (Fides in Prudentius'Psychomachia, „Classica Cracoviensia” 9 (2005) 19-21).

${ }^{32}$ Por. M. Starowieyski, ,Psychomachia” Prudencjusza czyli katecheza o cnotach i grzechach, „Ethos” 23 (2010) nr 4, 171-182.

${ }^{33}$ Przyjmuje określenie zastosowane przez J. Fontaine (Chrześcijańska literatura, s. 140-141).

${ }^{34}$ Por. Starowieyski, Wstęp, ŹMT 40, 34-36.

${ }^{35}$ Por. Fontaine, Chrześcijańska literatura, s. 143-145.

${ }^{36}$ Por. Augustinus, Confessiones IX 12, 32-33, ed. A. Trapè - C. Carena, NBA 1, Roma 19915, 286-288.

${ }^{37}$ M. Starowieyski, Wstęp, w: Muza chrześcijańska, t. 2: Poezja łacińska starożytna i średniowieczna, OŻ 10, Kraków 1992, 12.

${ }^{38}$ Por. Isidorus, Versus VI, CCL 113A, 217: „Ambrosius doctor, signis insignis et hymnis, / Enitet hic titulis, enitet eloquiis".
} 
spowinowaconym z Apolinarym Sydoniuszem ${ }^{39}$, którego twórczość wywarła zauważalny wpływ na jego poezję $e^{40}$. Przez ponad 20 lat (494-518) Awit pełnił posługę biskupa miasta Vienne w południowej Galii - zwalczał heretyków, zabiegał o utrzymanie ścisłych kontaktów Kościoła burgundzkiego z Rzymem, popierał prawowitego papieża Symmacha w walce $\mathrm{z}$ antypapieżem Wawrzyńcem, a w trosce o dyscyplinę kościelną zwołał w r. 517 synod w Épaon. Cieszył się też wielkim autorytetem wśród członków rodziny królewskiej ${ }^{41}$ : prowadził uczone dysputy teologiczne z ariańskim królem Burgundów Gundobadem, a jego syna, późniejszego króla - męczennika, św. Sigismunda, nawrócił na katolicyzm ${ }^{42}$. Awit z Vienne jako jedyny spośród poetów, których prezentuje czytelnikowi Izydor, zmarł w opinii świętości; jego liturgiczne wspomnienie przypada na 5 lutego. Uznawany przez historyków za wybitnego teologa-polemistę i reformatora życia kościelnego, był również autorem szeregu pism prozaicznych oraz poetą o wysokiej kulturze poetyckiej ${ }^{43}$. W Wierszach Sewilczyk nazywa Awita facundus oraz zachęca czytelnika do przeczytania skomponowanej przez niego „uczonej pieśni” (studiosum carmen) ${ }^{44}$. Chodzi prawdopodobnie o Carmina de spiritalis historiae gestis ${ }^{45}$, epicki poemat poświęcony wydarzeniom starotestamentalnym, którego treść w traktacie De viris illustribus Izydor streszcza w następujący sposób:

„Wydał pięć ksiąg ułożonych heksametrem. Pierwsza z nich mówi o stworzeniu świata, druga o grzechu pierworodnym, trzecia o Bożym wyroku, czwarta o potopie świata, piąta o przejściu przez Morze Czerwone"46.

${ }^{39}$ Z Sydoniuszem nie łączyły Awita, wbrew D.A. Sikorskiemu (Wstep, w: Grzegorz z Tours, Historie, thum. K. Liman - T. Richter, Tyniec - Kraków 2002, 129, n. 230), więzy pokrewieństwa. Żona poety Papianilla była córką cesarza Awitusa, por. Sydonius, Epistulae II 2; zob. także Cytowska - Szelest, Literatura rzymska, s. 335-336.

${ }^{40}$ Por. M. Roberts, The Jeweled Style. Poetry and Poetics in Late Antiquity, Ithaca 1989, 31.

${ }^{41}$ Por. Gregorius Turonensis, Historia Francorum II 34, PL 71, 230-232. Zob. J. Daniélou H.I. Marrou, Historia Kościoła, t. 1: Od początku do roku 600, tłum. M. Tarnowska, Warszawa 1984, 310-311.

${ }^{42}$ Por. Agobardus Lugdunensis, Adversus legem Gundobadi 13, PL 104, 124-125: „Qui [scil. Avitus] Gundobado in sua perfidia perdito, successorem eius Sigismundum regem ad fidem catholicam convertit". O męczeństwie króla Sigismunda zob. Gregorius Turonensis, Historia Francorum III 5-6, PL 71, 244-246; tenże, Libri miraculorum I 75, PL 71, 770-771; zob. także A. Rojewski, Zarys kultu liturgicznego św. Zygmunta w Polsce w okresie przedtrydenckim, RTK 14 (1967) z. 4, 113-122.

${ }^{43}$ Por. J. Fontaine, Naissance de la poésie chrétienne, Paris 1981, 256-260; Cytowska - Szelest, Literatura rzymska, s. 312-313; Szymusiak - Starowieyski, SWP 83.

${ }^{44}$ Por. Isidorus, Versus XI 5, CCL 113A, 217: „Perlege facundi studiosum carmen Aviti”; zob. Martialis XIV 185, 1, ed. F.G. Schneidewin: Marcus Valerius Martialis, Epigrammaton libri, Lipsiae 1866, 340: ,accipe facundi Culicem studiose Maronis”; XIV 183, 1, ed. Schneidewin, s. 339: ,perlege Maenio cantatas carmine ranas”; V 30, 3, ed. Schneidewin, s. 115: „facundi scoena Catulli”.

${ }^{45}$ Por. Avitus Viennensis, Carmina de spiritalis historiae gestis, PL 59, 323-370 lub MGH Auc. Ant. VI/2 201-274.

${ }^{46}$ Por. Isidorus, De viris illustribus 23, 2-5, ed. C. Codoñer Merino, Salamanca 1964, 146, thum. 
W tymże dziele wspomina ponadto o pięknej wierszowanej pochwale dziewictwa, którą „bardzo wykształcony w naukach świeckich” ${ }^{47}$ Awit skierował do siostry Fusciny. Jest to poemat De consolatoria castitatis laude ${ }^{48}$, drugi spośród zachowanych do naszych dni utworów poetyckich Awita, który Izydor ocenia wyjątkowo pochlebnie ${ }^{49}$. Dlaczego nie wspomniał o nim w Wierszach? Przecież w De viris illustribus opowiada o autorach i dziełach, które osobiście $\operatorname{czyta}^{50}$. Wydaje się, iż skupiając uwagę czytelnika na jednym poemacie Awita Sewilczyk wyraża swój zachwyt opowieścią o duchowej historii ludzkości, którą naśladował wykładając ludziom sprawy Boże w Raju utraconym John Milton $^{51}$.

Zauważmy, iż Izydor mógł darzyć twórczość Awita szczególnym zainteresowaniem nie tylko dla jej wyjątkowych walorów literackich, lecz również z powodu pewnego podobieństwa losów autora i swoich własnych. Brat Awita - Apolinary był biskupem Walencji; Awit dedykował mu oba wspomniane poematy ${ }^{52}$. Tymczasem posługę biskupią sprawowali również dwaj bracia Izydora - Leander (w Sewilli) ${ }^{53}$ oraz Fulgencjusz (w Astigi (obecnie Ecija) ${ }^{54}$, ich siostra Florentyna była zaś mniszką. Po śmierci rodziców Izydor został jako małe dziecko powierzony opiece rodzeństwa. Cała czwórka - podobnie jak Awit, Apolinary i Fuscina - darzyła się serdecznym uczuciem ${ }^{55}$. Izydor poświęcił Fulgencjuszowi traktat De officiis, a Florentynie, do której Leander

S. Bajko, w: Szymusiak - Starowieyski, Avit z Vienne, SWP 83 (wszystkie cytowane fragmenty $\dot{Z} y$ wotów, jeśli nie zaznaczono inaczej, są podane z niniejszego przekładu). Omówienie poematu Awita w: Cytowska - Szelest, Literatura rzymska, s. 313-316.

${ }^{47}$ Por. Isidorus, De viris illustribus 23, 1-2, ed. Codoñer Merino, s. 146: „Avitus episcopus, scientia secularium litterarum doctissimus".

${ }^{48}$ Por. Avitus Viennensis, Carmina de consolatoria castitatis laude, PL 59, 369-382 lub MGH Auct.Ant. VI/2 274-294.

${ }^{49}$ Por. Isidorus, De viris illustribus 23, 1-2, ed. Codoñer Merino, s. 146: „Scripsit et ad Fuscinam sororem de laude virginitatis librum unum pulcherrime compositum et eleganti epigrammate coaptatum".

${ }^{50}$ Izydor (De viris illustribus 17, 5-6, ed. Codoñer Merino, s. 143; 21, 5-6, ed. Codoñer Merino, s. 145) wyraźnie zastrzega, że nie będzie pisał o dziełach, które nie są mu znane.

${ }^{51}$ Por. J. Milton, Raj utracony I 31, tłum. M. Słomczyński, Warszawa 1974, 32; zob. J.E. Duncan, Milton's Earthly Paradise. A Historical Study of Eden, Minnesota 1972, 64.

${ }^{52}$ Por. Avitus Viennensis, Carmina de spiritalis historiae gestis Prol., PL 59, 323.

${ }^{53}$ Por. Isidorus, De viris illustribus 28, ed. Codoñer Merino, s. 149-150; P. Szczur, Leander z Sewilli, EK X 599-600.

${ }^{54}$ Por. Díaz y Díaz, Introducción general, s. 100-102; Krynicka, Izydor, s. 6-11.

${ }^{55}$ Por. Leander Hispalensis, Regula 21, PL 72, 873-894: „Postremo carissimam te germanam [scil. Florentinam] quaeso, ut me orando memineris nec iunioris fratris Isidori obliviscaris, quem quia sub Dei tuitione et tribus germanibus superstitibus parentes reliquerunt communes, laeti et de eius nihil reformidantes infantia, ad Dominum commearunt. Quem cum ego ut vere filium habeam nec temporale aliquid eius charitati praeponam atque in eius pronus dilectione recumbam, tanto eum charius dilige, tantoque Iesum exora pro illo, quanto nosti eum a parentibus terrenis fuisse dilectum". 
skierował pismo zachęcające do życia w dziewictwie ${ }^{56}$, dedykował De fide catholica contra Iudaeos ${ }^{57}$.

3. Juwenkus i Seduliusz. W kolejnych wersach analizowanego XI epigramatu Sewilczyk przedstawia czytelnikowi twórcę parafrazy biblijnej - Juwenkusa (Gaius Vettius Aquilinus Iuvencus) oraz równie wspaniałego, zdaniem Izydora, kontynuatora jego dzieła - Seduliusza (Sedulius Caelius). Juwenkus żył w IV w., był chrześcijańskim kapłanem. Wywodził się ze znakomitej hiszpano-rzymskiej rodziny, pochodził czy mieszkał zaś w Elwirze koło Grana$\mathrm{dy}^{58}$. Około $330 \mathrm{r}$. skomponował pierwszą chrześcijańską epopeję - poemat Evangeliorum libri $I V$, będący dość dokładną parafrazą Ewangelii wg św. Mateusza $^{59}$. W 4000 heksametrów daktylicznych przedstawił w nim miłującym epos Rzymianom vitalia gesta Christi $^{60}$, w porównaniu z którymi tracą wartość czyny bohaterów, opiewanych przez wcześniejszych epików, nawet tak bardzo podziwianego przez pogan Eneasza ${ }^{61}$. W prologu epopei Juwenkus nie zwraca się po natchnienie do Muz, lecz - jako pierwszy znany nam poeta błaga o pomoc Ducha Świętego. Prosi, by dzięki pokropieniu wodą z Jordanu stał się zdolny do godnego opiewania Chrystusa:

„Ergo age! sanctificus adsit mihi carminis autor

Spiritus, et puro mentem riget amne canentis

Dulcis Iordanis, ut Christo digna loquamur" ${ }^{\prime 2}$.

Wspomnijmy również, iż pierwszy epik-chrześcijanin dedykował swój poemat Konstantynowi Wielkiemu, którego ukazuje jako natchnionego ideą Chrystusowego pokoju, idealnego władcę i obrońcę Kościoła ${ }^{63}$.

Seduliusz żył w 1. poł. V w. Uczeni nie są zgodni co do jego pochodzenia z Hiszpanii, Galii, czy Italii, jak też co do tego, że - zgodnie z późniejszym przekazem - miał na stale mieszkać w Rzymie. W młodości tworzył utwory świeckie, które nie zachowały się do naszych czasów, natomiast po przyjęciu święceń kapłańskich zwrócił się ku twórczości religijnej. Wówczas stworzył epopeję w pięciu księgach pod tytułem Paschale carmen ${ }^{64}$, a także będącą komentarzem i uzupełnieniem jej prozową przeróbkę Paschale opus oraz dwa

\footnotetext{
${ }^{56}$ Por. P. Szczur, Leandra reguła, EK X 600-601.

${ }^{57}$ Por. Krynicka, Izydor, s. 19-22 i 28-31.

${ }^{58}$ Por. R.P.H. Green, Latin Epics of the New Testament. Juvencus, Sedulius, Arator, Oxford 2006, 8-9.

${ }^{59}$ Por. Iuvencus, Evangeliorum libri IV, ed. J. Huemer, CSEL 24, Vindobonae - Lipsiae 1891 lub PL 19, 53-346.

${ }^{60}$ Tamże Praef. 19, CSEL 24, 2: „,nam mihi carmen erit Christi vitalia gesta”.

${ }^{61}$ Por. Cytowska - Szelest, Literatura rzymska, s. 188-190.

${ }^{62}$ Iuvencus, Evangeliorum libri IV Praef. 25-27, CSEL 24, 2.

${ }^{63}$ Por. Fontaine, Naissance, s. 68-69.

${ }^{64}$ Por. Sedulius, Paschale carmen, ed. J. Huemer, CSEL 10, Vindobonae - Lipsiae 1885, 1-154 lub PL 19, 549-752.
} 
hymny ${ }^{65}$. W poemacie opowiada o będących przygotowaniem na przyjście Mesjasza wydarzeniach starotestamentalnych (ks. I-II) oraz o ziemskim życiu Chrystusa, Jego śmierci i zmartwychwstaniu (ks. II-V). Seduliusz podchodzi do swych źródeł z większą swobodą niż rzetelnie relacjonujący cuda, przypowieści, mowy oraz spory Jezusa z uczonymi w Piśmie Juwenkus. Autor Poematu paschalnego skupia się natomiast na cudach Chrystusa, w których przejawia się moc Boża i które swą niezwykłością dowodzą, że Jezus jest jedynym Zbawicielem świata. Nie waha się przed podaniem wynikających z jego własnych przemyśleń alegorycznych i mistycznych interpretacji opisywanych $\mathrm{w}$ Biblii wydarzeń ${ }^{66}$. Uzupełnia przekaz biblijny wiadomościami pochodzącymi z tradycji pozabiblijnych, chociażby wówczas, gdy opowiada o tym, że - zgodnie z prastarym chrześcijańskim podaniem - zmartwychwstały Pan ukazał się przede wszystkim swojej Matce ${ }^{67}$. Podobnie jak Juwenkus Seduliusz nawiązuje do aktualnych wydarzeń, a mianowicie zwalcza błędne nauki arian i macedonian ${ }^{68}$.

Za pomocą powtórzenia przydawki ambo na początku i na końcu wersu Sewilczyk dobitnie podkreślił równość obu określanych nią autorów. Analizując ten wers Louis Holtz dochodzi do wniosku, iż w odczuciu Izydora ci dwaj poeci „są nierozdzielni bądź uzupełniają się nawzajem" "69. Ukazuje ich jako wspaniałych mówców, znanych i wybitnych poetów, którzy hojnie poją czytelnika wodą z Bożego źródła ${ }^{70}$. Jak się wydaje, wymienienie Seduliusza obok Juwenkusa, którego jedynym dziełem jest poemat epicki, a także zaopatrzenie obu w jedną wspólną charakterystykę pozwala wnioskować, iż Izydor polecał oprowadzanemu po bibliotece czytelnikowi właśnie skomponowaną przez Seduliusza epopeję. W przekonaniu tym utwierdza nas lektura żywota Seduliusza zamieszczonego w De viris illustribus. Izydor wspomina w nim tylko jego poemat epicki w trzech księgach, a więc Poemat paschalny ${ }^{71}$. Zauważmy, iż w ten sposób poświadcza istnienie znanej nam z niektórych rękopisów wersji poematu podzielonego na trzy księgi, a nie na cztery - zgodnie z pierwotnym zamysłem autora ${ }^{72}$, ani nie na pięć, jak w wydaniach ogłoszonych drukiem ${ }^{73}$.

${ }^{65}$ Por. H. Wójtowicz, Wstęp, w: Sedulius Caelius, Opera omnia. Dzieła wszystkie. Tekst łacińsko-polski, tłum. i oprac. H. Wójtowicz, Lublin 1999, 7-10; Green, Latin Epics, s. 135-143.

${ }^{66}$ Por. Fontaine, Naissance, s. 250.

${ }^{67}$ Por. Sedulius, Paschale carmen V 360-365, CSEL 10, 140-141.

${ }^{68}$ Por. Wójtowicz, Wstęp, s. 10-16 i 19-20; Cytowska - Szelest, Literatura rzymska, s. 310-311.

${ }^{69} \mathrm{~L}$. Holtz, Les poètes latins chrétiens dans l'Espagne wisigothique, w: De Tertullien aux Mozarabes. Mélanges J. Fontaine, ed. L. Holtz - J.-C. Fredouille, t. 2: Antiquité tardive et christianisme ancien (VI ${ }^{e}-I X^{e}$ siècles), Paris 1962, 74.

${ }^{70}$ Por. Isidorus, Versus XI 6-8, CCL 113A, 217:,, Ecce Iuvencus adest Seduliusque tibi; / ambo lingua pares, florentes versibus ambo. / Fonte evangelico pocula larga ferunt".

${ }^{71}$ Por. tenże, De viris illustribus 7, ed. Codoñer Merino, s. 138.

${ }^{72}$ Por. Sedulius, Epistula ad Macedonium, ed. J. Huemer, CSEL 10, 12: „quattuor igitur mirabilium divinorum libellos".

${ }^{73}$ Por. Szymusiak - Starowieyski, SWP 352-353. 


\section{CHRZEŚCIJAŃSCY EPICY W INNYCH PISMACH SEWILCZYKA}

1. Proba. Nie ulega wątpliwości, iż w Wierszach Izydor z Sewilli nie omawia wszystkich znajdujących się w jego bibliotece dzieł. Nie wymienia na przykład gramatyków, z których prac tak często czerpał wiadomości, jak również autorów pism technicznych, geograficznych, historycznych; nie wspomina o wyciągach i kompilacjach, tak bardzo popularnych w jego czasach ${ }^{74}$.

Cennym źródłem naszej wiedzy o tym, jakich jeszcze autorów znał Sewilczyk, jest jego traktat De viris illustribus ${ }^{75}$. W tym piśmie, które jest kontynuacją podobnych dzieł Hieronima oraz Gennadiusza z Marsylii oraz stanowi swego rodzaju listę chrześcijańskich autorów, zalecanych przez Izydora ogółowi czytelników, uważa on za stosowne wspomnieć o Probie. Podaje, iż centonistka była żoną konsula Adelfiusza. Jego świadectwo jest zgodne z przekazem najstarszych rękopisów zawierających centon, na podstawie którego badacze utożsamiają jego autorkę z żyjącą w latach 322-370 Walerią Faltonią Probą, spokrewnioną z Anicjuszami potomkinią znakomitej senatorskiej rodziny Probusów ${ }^{76}$. Izydor zauważa, iż Proba jest jedyną kobietą zaliczaną do grona kościelnych pisarzy ${ }^{77}$. Omawiając jej $\operatorname{centon}^{78}$, zdradza, podobnie jak inni chrześcijańscy pisarze (Tertulian, Hieronim, Augustyn ${ }^{79}$, brak entuzjazmu wobec tego gatunku, mimo iż cieszył się on uznaniem wśród ogółu chrześcijan ${ }^{80}$. Jednakże wykazując się wyrozumiałością i bezstronnością, której najwyraźniej zabrakło jego wielkim poprzednikom, Sewilczyk stwierdza ostatecznie, iż układając z wierszy Wergiliusza opowieść o życiu Chrystusa, Proba pracowała na jego chwałę ${ }^{81}$ oraz - podobnie jak współcześni badacze ${ }^{82}$

${ }^{74}$ Por. Díaz y Díaz, Introducción general, s. 154; Krynicka, Wstęp, s. 568 oraz 575, n. 31.

${ }^{75}$ Zwraca na to uwagę J. Fontaine (Isidoro di Siviglia e la cultura del suo tempo, w: tenże, Culture et spiritualité en Espagne du IVE au VII siècle, London 1986, VI, 31.

${ }^{76}$ Część uczonych widzi w niej wnuczkę tej ostatniej, Anicję Faltonię Probę. Poglądy badaczy relacjonuje R.P.H. Green (Proba's Cento: Its Date, Purpose and Reception, CQ 45 (1995) 551-554).

77 Por. Isidorus, De viris illustribus 5, 1-2, ed. Codoñer Merino, s. 136: „Proba uxor Adelphi proconsulis femina inter viros eccesiasticos [...] posita sola".

${ }^{78}$ Por. Proba, Cento, ed. C. Schenkl, CSEL 16, Vindobonae 1888, 512-621.

${ }^{79}$ Por. Tertullianus, De praescriptione haereticorum 39, 3-7, PL 2, 52-53; Hieronymus, Epistula 53, 7, ed. I. Hilberg, CSEL 54, Vindobonae - Lipsiae 1910, 454; Augustinus, De civitate Dei 17, 15, ed. E. Hoffmann, CSEL 40/2, Pragae - Vindobonae - Lipsiae 1900, 247. Jak się wydaje, Izydor znał opinię Tertuliana o centonach, gdyż pisząc o Probie w swej encyklopedii (Etymologiae I 39, 26, PL $82,121)$ zdradza wpływ lektury wspomnianego wyżej fragmentu. Tegoż zdania są również J. Ziołkowski i M.C.J. Putnam (The Vergilian Tradition: The First Fifteen Hundred Years, Yale 2008, 475).

${ }^{80}$ Por. Starowieyski, Wstęp, ŹMT 40, 27-28; S. Ehrling, , De inconexis continuum”. A Study of the Late Antique Latin Wedding Centos, Göteborg 2011, 54.

${ }^{81}$ Por. Isidorus, De viris illustribus 5, 2-3, ed. Codoñer Merino, s. 136: ,in laude Christi versata est, componens centonem de Christo virgilianis coaptatum versiculis".

${ }^{82}$ Por. P. Dronke, Women Writers of the Middle Ages. A Critical Study of Texts from Perpetua († 203) to Marguerite Porete (†1310), Cambridge 1984, 286. 
- zachwyca się talentem ${ }^{83}$ tej, która odważyła się podjąć ambitnego zadania udoskonalenia księcia łacińskich poetów ${ }^{84}$. Na końcu Izydor informuje czytelnika, iż dziełko Proby zostało zaliczone do apokryfów ${ }^{85}$. Podobną informację znajdujemy również w Dekrecie Pseudogelazjańskim ${ }^{86}$, przypisywanym papieżowi Gelazemu piśmie anonimowego duchownego, który żył w VI w. w Galii, niemniej doskonale orientował się w poglądach i stosunkach panujących w Rzymie ${ }^{87}$. Autor Dekretu wymienia centon Proby w rozdziale piątym, wśród innych pism nie zaaprobowanych przez Kościół Rzymski ${ }^{88}$. Nie wiemy, czy milczenie Izydora o innych chrześcijańskich centonach wynika z jego nieznajomości tych pism, czy też uznał je za niegodne wzmianki, ograniczając się do omówienia najsłynniejszego spośród nich ${ }^{89}$.

2. Drakoncjusz. Kolejny chrześcijański epik, którego twórczość była znana biskupowi erudycie, to żyjący na przełomie V i VI w. Drakoncjusz (Blossius Aemilius Dracontius). Czytając relację Sewilczyka o nim, przekonujemy się co do słuszności opinii Carmen Codoñer Merino, która zauważa, iż tworząc Żywoty Izydor skupiał swą uwagę na dorobku pisarskim, a nie na biografiach omawianych w nim postaci. Interesowały go zatem wyłącznie ich dzieła, i to dzieła o treści chrześcijańskiej ${ }^{90}$. Ani słowem nie wspomina bowiem o barwnych, tragicznych kolejach losu tego twórcy; nie wymienia też jego dzieł o tematyce pogańskiej ${ }^{11}$. Drakoncjusz był gruntownie wykształconym potomkiem osiadłej w Afryce senatorskiej rodziny, sławnym mówcą i sędzią prokonsularnym w Kartaginie. Wygłoszeniem nie zachowanej mowy pochwalnej ku czci obcego władcy (króla Teodoryka? cesarza bizantyńskiego Zenona?) ściągnął

${ }^{83}$ Por. Isidorus, De viris illustribus 5, 4-5, ed. Codoñer Merino, s. 136: „Cuius quidem non miramur studium, sed laudamus ingenium”; wbrew Starowieyski, Wstęp, OŻ 10, 11.

${ }^{84}$ Por. Proba, Cento Praef. 3-4, CSEL 16, 568: „Maronem / mutatum in melius”. Zob. R.P.H. Green, Proba's Introduction to Her Cento, CQ 47 (1997) 548-549.

${ }^{85}$ Por. Isidorus, De viris illustribus 5, 5-6, ed. Codoñer Merino, s. 136: „Quod tamen opusculum legitur inter apocryphas scripturas insertum".

${ }^{86}$ Por. Decretum Gelasianum V 8, ed. E. von Dobschütz: Das Decretum Gelasianum de libris recipiendis et non recipiendis, TU 38, Leipzig 1912, 57: „Centonem de Christo vergilianis versibus compaginatum apocryphum"; zob. tamże, s. 209-210.

${ }^{87}$ Por. B. Altaner - A. Stuiber, Patrologia, tłum. P. Pachciarek, Warszawa 1990, s. 604.

${ }^{88}$ Por. przypis 86; zob. też M. Starowieyski, Wstep, w: Apokryfy Nowego testamentu, I: Ewangelie apokryficzne, cz. 1: Fragmenty. Narodzenie i Dzieciństwo Maryi i Jezusa, red. M. Starowieyski, Kraków 2006, 21.

${ }^{89}$ Por. Ehrling, „De inconexis continuum”, s. 24-29; Starowieyski, Wstęp, ŹMT 40, 26-28; T. Krynicka, Starożytny łaciński centon: próba przybliżenia (na przykładzie „Centonu weselnego” Auzoniusza), VoxP 32 (2012) t. 57, 359-378.

${ }^{90}$ Por. C. Codoñer Merino, La suerte de los libros, „Filologia Mediolatina” 9 (2002) 41.

${ }^{91}$ Są to: składający się z dziesięciu utworów o tematyce antycznej zbiór Pieśni rzymskie (Romulea), epylion Tragedia Orestesa (Orestis tragoedia) oraz napisany w więzieniu w celu zjednania łaskawości rozgniewanego władcy poemat Zadośćuczynienie (Satisfactio), por. Cytowska - Szelest, Literatura rzymska, s. 357 i 362-366. 
na siebie gniew króla Wandalów Gutamunda i został wtrącony do więzienia, w którym spędził wiele lat. Izydor podaje o nim jedynie co następuje:

„Drakoncjusz ułożył poemat w heksametrach o sześciu dniach stworzenia świata; jest on napisany w sposób znakomity i kunsztowny"92.

Sewilczyk ma na myśli utwór, który najwcześniejsi wydawcy, idąc w jego ślady, tytułowali Hexaëmeron, a który od czasów wydania przez Fryderyka Vollmera znany jest jako Laudes $D e i^{93}$. Ten napisany w mrocznych więziennych lochach poemat, który rozsławia wielkość, miłość i miłosierdzie Stwórcy oraz piękno stworzenia ${ }^{94}$, cieszył się w wizygockiej Hiszpanii niezwykłą poczytnością. Teolog i poeta, biskup Toledo Eugeniusz $(\dagger 658)^{95}$ na rozkaz króla Chindaswinta przepracował nawet jego pierwszą część i uzupełnił opis stworzenia świata w relację o siódmym dniu, w którym Stwórca odpoczywał ${ }^{96}$. Zauważmy, iż porównując przytaczane przez encyklopedystę fragmenty poematu Drakoncjusza oraz jego przeróbkę autorstwa Eugeniusza, dochodzimy do wniosku, iż biskup Toledo korzystał prawdopodobnie z tego samego manuskryptu co Izydor, lub z jego odpisu czy też z rękopisu o podobnej proweniencji. Przyjmują bowiem podobne, niekiedy błędne lekcje oryginalnego tekstu ${ }^{97}$.

Chwile prawdziwego wzruszenia przeżywa badacz, który czytając zgromadzone w nieistniejącej już bibliotece Izydora dzieła dawnych poetów zauważa, iż wzbudzają w nim podobny zachwyt, jaki wzbudzały w pokoleniach czytelników. Pełnymi natchnienia fragmentami księgi pierwszej Laudes Dei, w której Drakoncjusz opisuje stworzenie Ewy i początki miłości między prarodzicami ludzkości, zachwycał się między innymi Kazimierz Morawski ${ }^{98}$.

3. Werekundus z Junca. Jednak buszowanie w antycznych skriniach staje się prawdziwie ekscytującą przygodą dopiero wówczas, gdy ich właściciele

${ }^{92}$ Isidorus, De viris illustribus 24, ed. Codoñer Merino, s. 146: „Dracontius composuit heroicis versibus Hexaemeron creationis mundi, et luculente quidam compositeque scripsit”, thum. własne.

${ }_{93}$ Por. MGH Auct.Ant. XIV, Berolini 1905, 23-113. Autorka artykułu korzystała z następującego wydania: Dracontii De Laudibus Dei, ed. F. Vollmer, w: Poetae Latini Minores, t. 5, Lipsiae 1914, 1-82.

${ }^{94}$ Por. Fontaine, Naissance, s. 252-256.

${ }^{95}$ Por. Szymusiak - Starowieyski, Drakoncjusz, SWP 125 (błędnie zamiast „Eugeniusz” - „Julian”), zob. tamże.

${ }^{96}$ Por. Eugeniana recensio Laudum Dei, ed. Vollmer, MGH Auct.Ant. XIV, Berolini 1905, 27-69.

${ }^{97}$ Użyte przez Drakoncjusza sibilus (por. Laudes Dei I 514-515) staje się w Etymologiach suillus, por. Etymologiae XII 2, 37 (ed. André, s. 119); rękopisy zawierające Hexaëmeron poświadczają suillus, sivilus oraz sibilus, zob. Hexaëmeron 397; por. komentarz J. André, w: Isidore de Séville, Étymologies. Livre XII, s. 119, n. 184.

${ }^{98}$ Por. Dracontius, Laudes Dei 362-448, ed. Vollmer, s. 18-22. Zob. K. Morawski, Zarys literatury rzymskiej, Kraków 1922, 398-399. 
wspominają o pismach dziś zaginionych. W drugiej, bardziej obszernej wersji De viris illustribus, na którą składają się zarówno relacje o chrześcijańskich pisarzach autorstwa Izydora, jak również żywoty pochodzące od nieznanego autora, który żył w VI w. w Afryce, czytamy o Werekundusie z Junca9", mało znanym dziś autorze, mimo że w poł. VI w. było o nim głośno nawet na dworze cesarskim. Jako przeciwnik polityki Justyniana wymierzonej przeciw Trzem Rozdziałom został wezwany do Konstantynopola; stamtąd uciekł do Chalcedonu, gdzie w 552 r. zmarł ${ }^{100}$. Anonimowy autor podaje, że Werekundus był wymownym i wykształconym afrykańskim biskupem; napisał dwa niewielkie poematy epickie. W jednym z nich ,opłakuje w żałosnych pieniach swoje występki" ${ }^{101}$. Jest to umoralniająco-dydaktyczna Carmen de satisfactione poenitentiae, która zachowała się do czasów współczesnych ${ }^{102}$. W drugim zaś opisuje zmartwychwstanie i sąd ostateczny ${ }^{103}$ : jest to zaginiony epos $D e$ resurrectione et iudicio, którego znajomości możemy, jak myślę, pozazdrościć autorowi Żywotów, mimo iż Berthold Altaner oraz Alfred Stuiber uważają, iż heksametry Werekundusa są „,nieco chropowate"104. Czy poemat ten był znany Izydorowi z Sewilli? Czy w swoich pismach uczony biskup na pewno wspomniał o wszystkich poetach, których czytał? Odpowiedzi na te pytania mogą dostarczyć jedynie wnikliwe badania źródeł genialnego kompilatora; dziś pozostają one bez odpowiedzi.

\section{IV. „BONA CUM TANTA POTES, QUID TIBI CALIRROEN?” (VERSUS XI 10)}

Głównym tematem twórczości Juwenkusa, Seduliusza, Awita, Drakoncjusza, Werekundusa i wielu innych, znanych i nieznanych chrześcijańskich twórców, stał się Chrystus. Jego słodka miłość rozbrzmiewała w ich ustach, Jego zaś misterium uznawali za najbardziej fascynującą tajemnicę w dziejach ludzkości ${ }^{105}$. Świadomi swej ludzkiej nędzy tworzyli, by w ten sposób

${ }^{99}$ Por. C. Codoñer Merino, Estudio de la obra, w: El de viris illustribus de Isidoro de Sewilla. Estudio y edición crítica, Salamanca 1964, 20-31.

${ }^{100}$ Por. Altaner - Stuiber, Patrologia, s. 636.

${ }^{101}$ Isidorus, De viris illustribus 7, PL 83, 1088, thum. A. Bober, AP 345.

${ }^{102}$ Por. Verecundus, Carmen de satisfactione poenitentiae, ed. R. Demeulenaere, CCL 93, Turnhout 1976, 205-214. Zob. Cytowska - Szelest, Literatura rzymska, s. 306.

${ }^{103}$ Por. Isidorus, De viris illustribus 7, PL 83, 1088: „Verecundus, Africanus episcopus, studiis liberalium litterarum disertus, edidit carmine dactylico duos modicos brevesque libellos, quorum primum de Resurrectione et Iudicio scripsit, alterum vero de Poenitentia, in quo lamentabili carmine propria delicta deplorat".

${ }^{104}$ Altaner - Stuiber, Patrologia, s. 636.

${ }^{105}$ Por. Sedulius, Hymnus 1, 1-2, CSEL 10, 155: „Cantemus, socii, Domino, cantemus honorem, / Dulcis amor Christi personat ore pio”; 55-56, CSEL 10, 159: „Filius hic hominis est maxima quaestio mundi: / nobiscum Deus est filius hic hominis". 
rozsławiać Jego imię $e^{106}$ i osiągnąc zbawienie ${ }^{107}$. Prawdy nauki objawionej wyrażali jednak tak, jak nauczyli ich podziwiani przez nich poeci klasyczni. Chrześcijańska poezja wyrastała z poezji pogańskiej, nie zrywała z nią więzi i starała się ją naśladować ${ }^{108}$. Chrześcijańscy twórcy nie tylko ofiarowali swoim czytelnikom nowe poematy, zawierające ważne dla nich, bliskie im chrześcijańskie treści, ale ratowali też od zapomnienia dawną literaturę, którą niejako wcielali do swoich epopei. Czy opowiadając o Trójjedynym Bogu w heksametrach, które do niedawna rozsławiały Eneasza, szokowali wiernych ${ }^{109}$ ? Być może. Nie ulega wątpliwości, że postępując w ten sposób dostarczali im również wiele radości, ambitnej rozrywki i powodów do wzruszeń. Makrobiusz pyta, czy istnieje większa przyjemność niż słuchanie dwóch znakomitych poetów, mówiących to samo - inaczej ${ }^{110}$ ? Czyż jednak nie dorównuje jej przyjemność słuchania poetów, którzy mówią co innego, ale w podobny sposób?

Nie wiemy zbyt wiele o recepcji pierwszych chrześcijańskich epików przez współczesnych im pogan i chrześcijan. Możemy przypuszczać, iż byli dumni z tych, którzy odważyli się - jak to ujął Hieronim - podporządkować wzniosłą prawdę Ewangelii wymogom metrum ${ }^{111}$. W czasach Izydora mieszkańcy Półwyspu Iberyjskiego nie tylko rozczytywali się w utworach chrześcijańskich twórców ${ }^{112}$, lecz wręcz usiłowali zastąpić nimi lekturę autorów pogańskich ${ }^{113}$. W bibliotece - i w sercu - biskupa Sewilli oraz jego współczesnych było jednak miejsce dla jednych i dla drugich. W Wierszach Izydor ze swadą zachęca swego czytelnika, aby odtąd nie ulegał czarom pieśni pogańskich poetów. Uzasadniając tę zachętę, odsyła go do poetów chrześcijańskich i powiada: „Dobra tak wielkie posiadasz, na cóż ci Kalliroe?”"114 Źródeł o takiej nazwie w starożytności było wiele. Jednak niezależnie od tego, czy Sewilczyk utożsamia je z Hippokrene na Helikonie w Beocji, czy z poświęconym Apollonowi źródłem kastalskim bijącym na Parnasie, czy też - wierny swemu zamiłowa-

${ }^{106}$ Por. Prudentius, Carmina. Praefatio 34-36, ed. M.P. Cunningham, CCL 126, Turnhout 1966, 2: „atqui fine sub ultimo / peccatrix anima stultitiam exuat: / saltem voce Deum concelebrat, si meritis nequit"; zob. T. Kołosowski, Autobiograficzna refleksja Prudencjusza nad własnym życiem u progu starości, VoxP 31 (2011) t. 56, 324-325.

${ }^{107}$ Por. Iuvencus, Evangeliorum libri IV. Praefatio 21-23, CSEL 24, 2: „hoc [scil. opus] etenim forsan me subtrahet igni / tunc, cum flammivoma descendet nube coruscans / iudex, altithroni genitoris gloria, Christus".

${ }^{108}$ Por. Starowieyski, Wstęp, OŻ 10, 7; Roberts, The Jeweled Style, s. 123-124.

${ }^{109}$ Por. Starowieyski, Wstęp, ŹMT 40, 24-25.

${ }^{110}$ Por. Macrobius, Saturnalia V 3, 16, ed. J. Willis, Leipzig 1970, 250: „Quid enim suavius quam duos praecipuos vates audire idem loquentes?"

${ }^{111}$ Por. Hieronymus, Epistula 70, 5, CSEL 54, 707-708: „Iuvencus presbyter sub Constantino historiam Domini Salvatoris versibus explicavit nec pertimuit evangelii maiestatem sub metri leges mittere".

112 Por. Green, Latin Epic, s. 353-355.

113 Por. Holtz, Les poètes, s. 75-76.

${ }^{114}$ Isidorus, Versus XI 9-10, CCL 113A, 217: „Desine gentilibus iam inservire poetis. / Bona cum tanta potes, quid tibi Calirroen?" Por. Fontaine, Naissance, s. 288-289. 


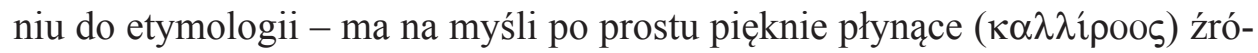
$\mathrm{d}^{115}$, możemy być pewni, iż przyznaje wyższość nad wodami darzącymi natchnieniem pogańskich poetów Chrystusowi - Źródłu wody żywej (por. J 4, 10-14), którego opiewają poeci chrześcijańscy.

\section{„DESINE GENTILIBUS IAM INSERVIRE POETIS...”(VERSUS XI 9). CHRISTIAN EPICS IN THE ISIDORE'S OF SEVILLE LIBRARY}

Isidore of Seville (560-636) is rightly considered to be one of the most important teachers of the medieval Europe. He wrote numerous didactic works on catholic doctrine, biblical exegesis, history, grammar, natural sciences etc. Isidore was neither a scientist nor an independent thinker, but indeed he was a genius of compilation. He spent his youth in the famous library of the bishops of Seville, where he stored knowledge by studying Holy Scriptures and works of classic and Christian authors. This library was destroyed, but we could strive to recreate its catalogue reading the books written by Isidore. In his Versus in bibliotheca Isidore tells us about authors he knew. We find among them Christian poets - Prudentius, Iuvencus, Sedulius, Avitus Viennensis. In Etymologiae Isidore presents to the reader Dracontius, and in De viris illustribus he admires talents of the centonist Proba. Isidore's knowledge of Christian epics and the high regard he had for them tell us a lot not only about literary tastes of the well-educated bishop, but about the culture of reading of inhabitants of Visigothic Spain in the seventh century as well.

Słowa kluczowe: Izydor z Sewilli, starożytna łacińska poezja chrześcijańska, chrześcijańscy epicy, centon, parafraza biblijna.

Key words: Isidore of Seville, ancient Latin Christian poetry, Christian epics, biblical paraphrase.

${ }^{115}$ Por. komentarz T. Krynickiej, w: Św. Izydor z Sewilli, Wiersze XI 8-10, VoxP 27 (2007) t. $50-51,575$, n. 30 . 
